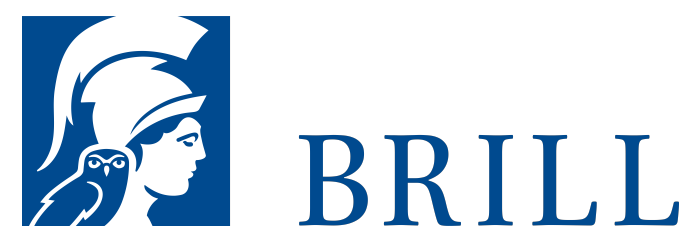

\title{
Kölner Papyri (P. Köln) Band 15
}

Authors: Thomas Backhuys, Charikleia Armoni, Robert W. Daniel, Jannik Korte, Klaus Maresch, Gesa Schenke, Alkestis A. Spinou, and Wolfgang Wegner

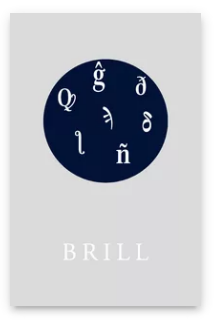

Pages: $\mathrm{X}+346$ Seiten, $79 \mathrm{~s} / \mathrm{w}$ Abb.

Language:

German

Subjects:

Ancient History, Classical Studies Publisher: Brill | Schöningh

Series:

Sonderreihe der Abhandlungen Papyrologica Coloniensia, Volume: 7/15

E-Book (PDF)

Released online: 22 Jun 2020 ISBN: 978-3657-78858-3 List price

Paperback

Publication date: o8 Sep 2017 ISBN: 978-3506-78858-о 
For more information see brill.com

Order information: Order online at brill.com +44330 333 0049 | customerservices@brill.com Submission information: brill.com/authors

Titles published by Brill | Fink, Brill | mentis or Brill | Schöningh: +49(o)715413279216| brill@brocom.de 